\title{
The Dynamic Evolution Mechanism of Heterogeneous OWOM-An Improved Viral Marketing Model
}

\author{
Mengjie Liao ${ }^{1}$, Lin $\mathrm{Qi}^{2, *}$ and Jian Zhang ${ }^{2, *}$ \\ 1 College of Economics and Management, China Agricultural University, Beijing 100083, China; \\ liaomengjie_cau@163.com \\ 2 College of Economics and Management, Beijing Information Science and Technology University, \\ Beijing 100192, China \\ * Correspondence: qilin@bistu.eu.cn (L.Q.); zhangjian@bistu.eu.cn (J.Z.); Tel.: +86-186-1186-3382 (L.Q.); \\ +86-139-1032-0041 (J.Z.)
}

Received: 8 January 2020; Accepted: 24 February 2020; Published: 1 March 2020

\begin{abstract}
The negative impact of brand negative online word-of-mouth (OWOM) on social images in social media is far greater than the promotion of positive OWOM. Thus, how to optimize brand image by improving the positive OWOM effect and slowing the negative OWOM communication has turned into an urgent problem for brand enterprises. On this basis, we analyze the evolution process of the OWOM communication group of the social media brand network based on the SOR (stimulus-organism-response) theory of psychology. Through constructing the heterogeneous brand OWOM communication dynamic model and conducting the multi-agent-based simulation experiment, the dynamic visualization of brand OWOM communication effect combined the thinking model of viral marketing is realized. Experiments show that the ability of brand communicators to persuade has a direct impact on the persistence and breadth of brand communication. When the acceptance of the consumer market is high, the negative OWOM of the brand has a relatively huge impact on consumers.
\end{abstract}

Keywords: OWOM (online word-of-mouth); computational experiment; SOR; information dissemination model

\section{Introduction}

Technological development and business model innovation have spawned an experience economy centered on the individual needs of customers. In an experience economy environment, brand companies concentrate on achieving customer satisfaction by creating a sound consumer experience. As a consumer's comprehensive evaluation of brand experience, word-of-mouth (WOM) is the most direct feedback on the consumer experience, and provides a reference for the consumer to make purchase decision [1]. The OWOM communication in the traditional sense is limited by the region, means, time, and local social relations. In this case, a bad consumer experience can hardly form a scale through OWOM communication, which has attracted the attention of brand enterprises. The rapid development of the mobile Internet has reduced the social cost of consumers, which has also contributed to social media featured with a large user base and convenient information sharing. In the era of social media, consumers are no longer willing to be passive "recipients" of brand advertisements, and instead, they spontaneously transform into active "spreaders" of brand information [2]. Then, online word-of-mouth (OWOM) communication has emerged as the times require, gradually becoming the most convenient channel for consumers to obtain brand information [3].

To a great extent, OWOM affects consumers' perceptions of brands and purchase decisions. Compared with brand information provided by the manufacturer, consumers generally believe that 
brand evaluation information given by other users has higher credibility and reference value [4]. Additionally, the comparative study of OWOM influence also shows that OWOM is heterogeneous. Negative OWOM has a much weaker effect on consumer purchasing behavior than positive OWOM [5]. Compared with positive OWOM, consumers in social media are more dependent on negative OWOM, which spreads wider [6,7]. Besides, negative comments about brands can even evolve into high-profile public opinion hotspots through consumer debates $[8,9]$. Consequently, it directly reduces consumers' willingness to purchase the corresponding products, and even undermines the corporate brand image [10].

Therefore, brand companies pay more attention to the brand's OWOM, especially the negative impact of negative OWOM on brand image. However, in this process, it is generally confused with the following questions: How to improve brand image by increasing the brand's positive OWOM? How to reduce the negative impact of brand negative OWOM? How to develop a brand marketing strategy to achieve the optimization of brand OWOM communication effect?

Confronted with the above-mentioned real problems, some instructive research using the viral marketing model and its evolution model results have been obtained. In traditional research on brand communication, brand OWOM information is defined as a positive brand reputation by default [11], and the distinction between OWOM information attributes is not considered, while negative OWOM is also ignored. Thus, the weakening effect of purchasing behavior appears.

In view of the practical problems that brand enterprises face and the shortcomings of existing research, this study focus on the dynamic evolution mechanism of heterogeneous OWOM based on an improved viral marketing model. The second section reviews the literature on enterprise brand OWOM communication and viral marketing modeling in brief. The following section analyzes the psychological process of individual OWOM communication in different brands. The further section explores an evolution mechanism of the social media consumer brand OWOM communication group for constructing a dynamic model concerning heterogeneous OWOM communication of social media brands with positive and negative OWOM as a double-infected virus are in Section 4. Six types of scenarios and 28 sets of sub-experiments are listed in Section 5 and, finally, the results are discussed.

Compared to current research with a single positive OWOM based on the traditional epidemic diseases model (e.g., SI, SIR, SEIR, etc.), this study aims to reflect the dynamics of a brand's heterogeneous OWOM effect in social media to some extent through multi-group multi-agent-based behavior simulation experiments. The evolution law provides a more practical reference for the development of brand network social network brand promotion strategy.

\section{Literature Review}

\subsection{Enterprise Brand OWOM Communication}

The existing research has formed a certain research accumulation around the "motivation (cause)-propagation process (passing)-propagation effect (result) of OWOM." Among them, the research hotspots of the dissemination process mostly focus on the communication mode and mechanism [12], the public opinion monitoring and data mining of OWOM communication [13], and the re-distribution of brand OWOM [14], especially in the positive and negative OWOM communication issues. Regarding research methods, the research methods of OWOM communication show diversity when system dynamics [15], social network analysis [16], agent-based modeling and simulation [17,18], and viral marketing $[4,19]$ are included. Among them, SIR and its improved model are in line with the characteristics of brand OWOM communication users, OWOM communication, and the wider range, which are also featured with excellent applicability in brand OWOM communication research $[16,20]$.

\subsection{Viral Marketing Modeling}

Scholars have carried out a lot of research and exploration on the theory and application of viral marketing, such as the implementation of the framework construction, model design and algorithm 
optimization [21-23], the spread mechanism of viral information [24-26], the social activities based on the network platform [27-29], and the simulation experiments [30,31]. Successful viral marketing research cases have greatly expanded the application scenarios in this field. Companies and even public institutions have focused more on this effective marketing mode, such as telecom companies, insurance companies, the medical industry, the food industry, the automobile industry, libraries, etc. [23,32-35]. Back to the research on viral marketing modeling, the mechanism of virus diffusion [25], the transmission mode of virus marketing in the complex network environment [30], and the new transmission framework [36] using incremental clustering have been proposed in recent years.

According to previous research, it can be found that current viral marketing is still in the practice and academic exploration stage. Most of the research work still focuses on single-factor analysis and theoretical interpretation. The heterogeneous OWOM model for brand enterprise viral marketing in the mobile Internet environment has not appeared.

\section{Conceptual Model}

\subsection{Social Media Brand Heterogeneous OWOM Spread Individual Behavior Motivation}

The consumer behavior concerning participation in brand OWOM communication in social media depends on consumers' perceptions and attitudes toward brands through social interaction, which is their external response to brand perception [37]. Social media provides consumers with an environment to comprehend the brand, and online interaction between consumers helps the brand's channels be deeply understood. In terms of individual consumers, the process of understanding the brand, perceiving it, and spreading the brand's reputation is that of the consumer's inner psychological activity, which is the process of generating cognitive, emotional, and physical reactions in line with external stimuli [38].

In the field of psychology research, to explore the relationship between environment and body behavior, Mehrabian and Russell first proposed the stimulus-organism-response (SOR) model in 1974, assuming that the external environment can affect the individual's cognitive and emotional responses to alter the individual's behavioral intentions [39]. Since then, numerous scholars have extended the theory to network brand marketing related fields to probe the relationship among network environment, the social network, brand OWOM, and user behavior [40].

In social media, the dynamic process of consumer-to-brand OWOM communication can be perceived as a psychological process in which consumers are stimulated by external information-organism perception-to take action [41,42]. In this regard, the present study defines the interpersonal interaction around brand OWOM on social media as the stimulus factor of consumers. Furthermore, consumers' perception of brand and brand satisfaction is the organism factor. The willingness of brand OWOM communication is a response factor; the social media consumer brand OWOM spread SOR model is built (Figure 1).

The initial state of social media includes various forms of brand OWOM communication participants. Through the interpersonal interaction in social media, brand OWOM participants will form an individual brand awareness after receiving brand reputation information and developing certain brand consciousness. Then, this psychological judgment of corresponding brand satisfaction can be employed as the basis for brand communication, thus changing their behavior and turning them into a new form of brand OWOM communication participants. When the advertising willingness of all individuals in the group disappears with time, the group's popularity of brand OWOM communication is exhausted. As a result, the group will no longer use the brand as a topic to generate interpersonal interaction, and those participants all evolve into brands. At that time, the brand's OWOM communication activities will be terminated. 


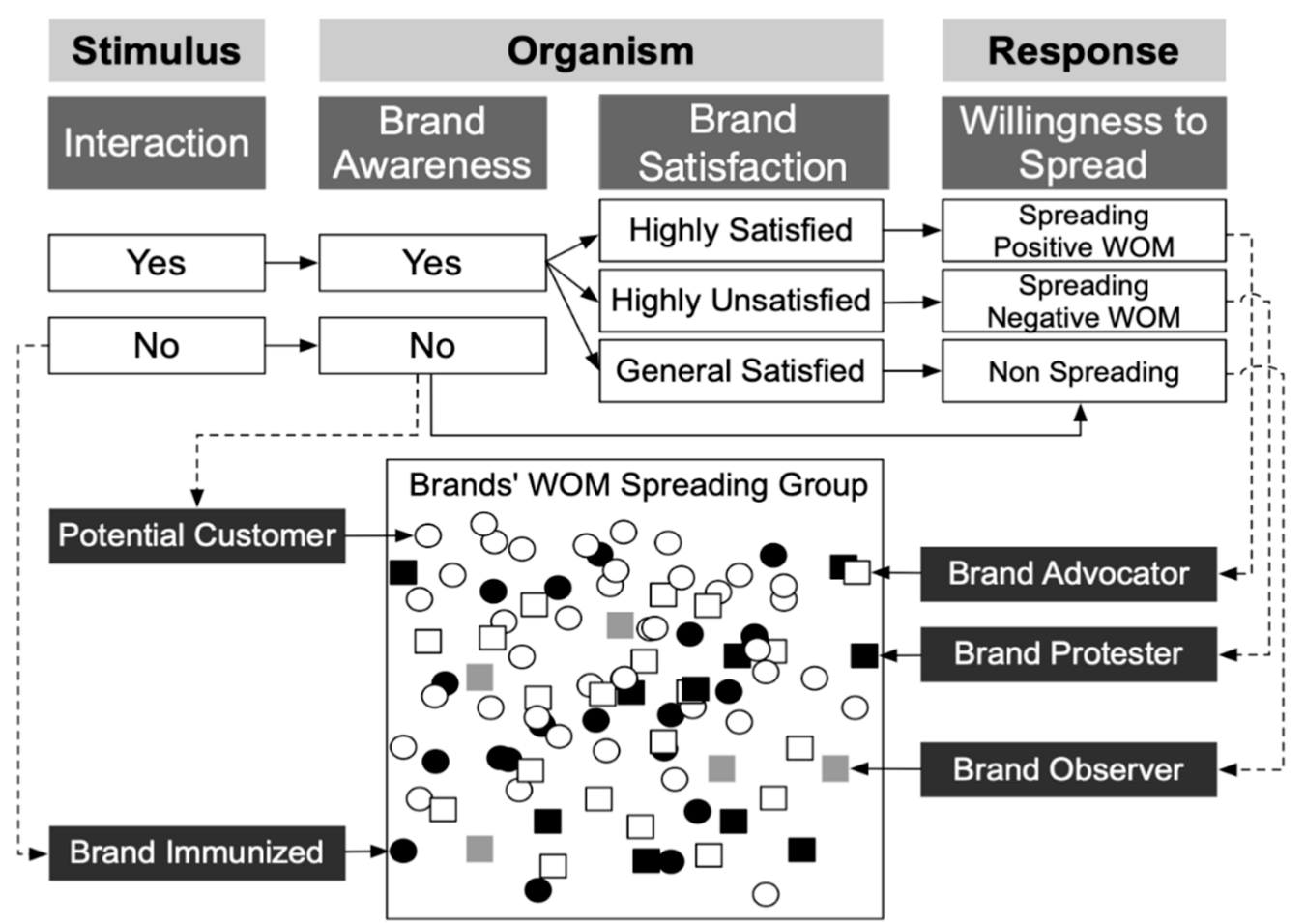

Figure 1. Social media consumer brand online word-of-mouth (OWOM) communication stimulus-organism-response (SOR) model.

\subsection{The Evolution Mechanism of the Brand Heterogeneous OWOM Communication Group in Social Media}

As the carrier of brand OWOM communication, social media can be abstractly defined as a network space containing a limited user group. Users can browse brand OWOM information published by other users on the social network platform for the sake of brand understanding. OWOM communicators use information transfer activities, such as posting, forwarding, and commenting, to spread their evaluation of the brand.

According to the social media consumer OWOM communication model (Figure 1, this picture is produced by authors), individual consumers have various choices for brand cognition, satisfaction, and willingness to spread. Therefore, brand communication participants are in light of their acceptance of brand information. The satisfaction of the brand and the participation of the brand OWOM communication process play a role in choosing the brand OWOM delivery strategy. This study abstracts this dynamic process into the evolution mechanism of the brand OWOM communication group (Figure 2, this picture is produced by authors).

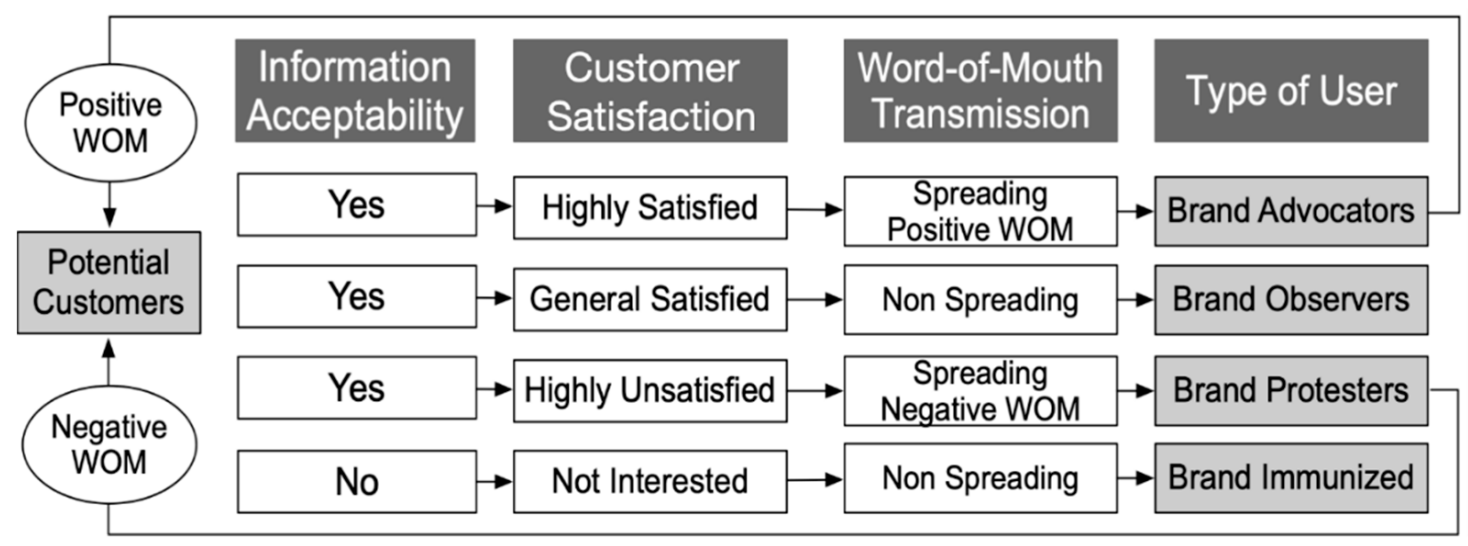

Figure 2. Evolutionary mechanism of the brand heterogeneous OWOM communication group in social media. 
To describe the communication effect of positive and negative brand evaluation in social media, a dynamic model of brand heterogeneous OWOM communication, including five types of OWOM communication groups, is constructed. Social media users can decide whether to meet consumers in accordance with their acceptance of brand information. After the exchange of the information, the user will enhance his or her satisfaction with the brand in light of the perception of the brand information. Thus, his or her participation in brand communication activities will be determined to achieve continuous changes to the strategy held. According to their brand OWOM communication strategies, groups can be split into five categories: brand advocators, brand protesters, potential consumers, brand observers, and people named "brand immunized" immune to the brand.

As brand OWOM communication groups, brand advocators and brand protesters disseminate both positive and negative brand OWOM information. Satisfaction and OWOM communication are $\mathrm{u}$-shaped [1]. It means that when there are high satisfaction and dissatisfaction, OWOM communication has the highest willingness. Thus, brand advocators are highly satisfied with the brand, and brand-responders show extreme discontent. Because the customer satisfaction of brand advocators and brand protesters tends to be extreme, the evaluation of the opposite attitude has a high degree of neglect, avoidance, and willingness to resist [38]. It is challenging to change this situation via customer communication, since consumers normally will insist on their perception of the brand despite other people's evaluation. Therefore, this study defines brand OWOM information disseminated by other groups that does not affect brand advocators and brand resistance. In the process of brand OWOM communication, if the outside world does not give continual stimulation, brand advocators and protesters often lose their enthusiasm over time, and get tired of constantly swearing or smashing in social media. Eventually, they will no longer spread brand information, and then turn into a brand observer, or even a person immune to the brand.

Potential consumers, brand observers, and people immune to the brand are the receiving groups of brand reputation in social media, and do not conduct spontaneous OWOM communication activities. Since potential consumers do not get to know any brand information, they do not understand it and their brand satisfaction is 0 . After accepting the positive and negative brand reputation, they will change to the corresponding brand OWOM communication group in line with their brand satisfaction. Brand observers have been exposed to brand information and are in a low satisfaction curve. Generally, they are satisfied, but still hold a wait-and-see attitude toward the brand and are interested in further receiving more relevant information. In terms of potential consumers and observers, after receipt of brand reputation information on social media, it is easier to change their attitude toward the brand due to their high acceptance of brand information. "Brand immunized" may refer to the netizens who mistakenly clicked in and reject all brand information. It may also be those people who do not show interest in continuing to accept information after contacting the brand data. It is the information insulation in the group, and those netizens neither spread nor receive information. "Brand immunized" are immune to all brand information; that is, positive and negative brand reputation cannot change the acceptance of information by people who are immune to the brand.

\section{Model Setup}

\subsection{The Brand Heterogeneous OWOM Communication Model in Social Media}

The SIR model and its improved model have been extensively used in the fields of public opinion, risk, and emergencies [43]. The spread of brand OWOM in social media is the dissemination of information between disparate subjects, satisfying the basic assumptions of the virus propagation model. Subject behavior is consistent with the random walk hypothesis. However, the conventional SIR-based information dissemination model merely contains three sorts of information transmission subjects. The information has no heterogeneity, which fails to describe the influence of positive and negative brand OWOM on social media in brand communication. In addition, the model does not involve the transformation of the information transmitter itself. The current work aims to 
describe the dissemination effect of heterogeneous brand OWOM of social media. Hence, the SIR model with universal application and strong applicability in the research of network information communication dynamics is taken as the prototype. Brand positive and negative OWOM is deemed as two types of infectious viruses: $I^{+}$and $I^{-}$. Based on the mechanism of brand heterogeneous OWOM communication in social media, a dual-virus infection model composed of five kinds of brand-based OWOM communication subjects, including brand advocators, brand protester, potential consumer, brand observer, and brand immunized, was constructed. The mechanism of brand OWOM system dynamics propagation is shown in Figure 3.

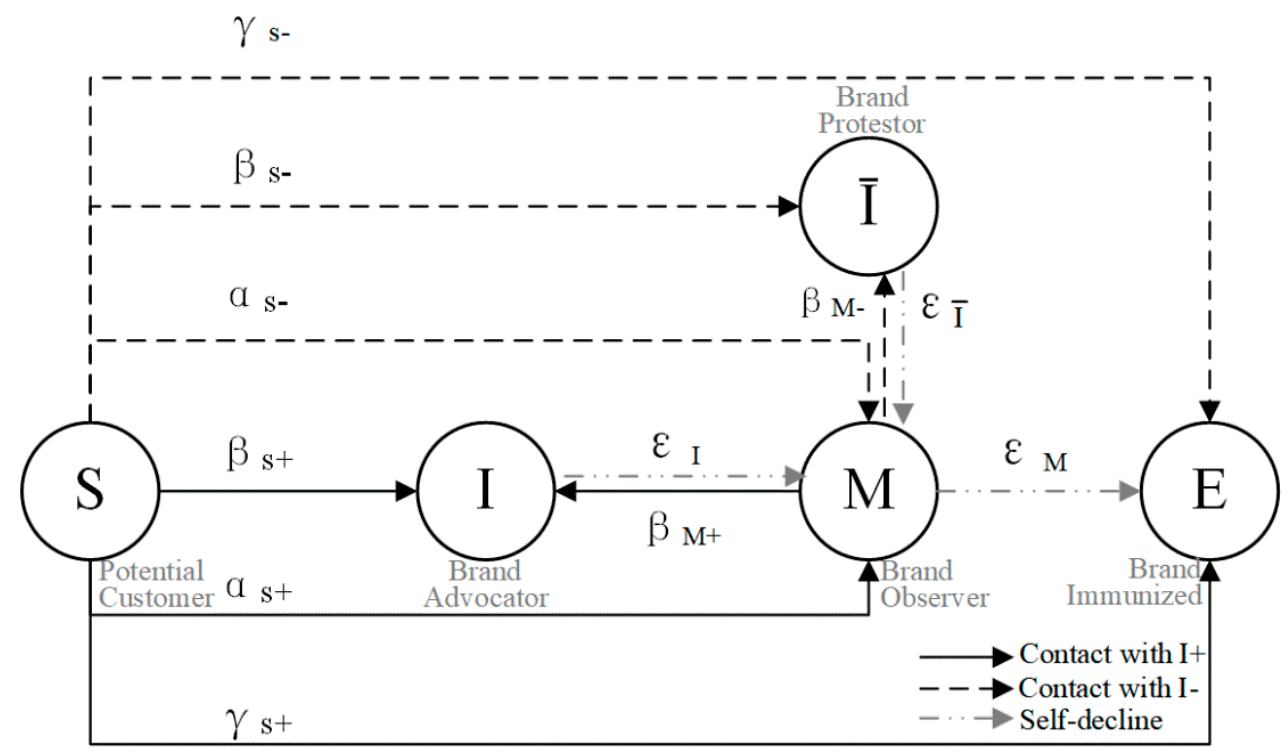

Figure 3. The brand heterogeneous OWOM virus infection model in social media.

The social media brand OWOM communication group state transfer equation is listed below:

$$
S(0) \rightarrow M(t)+S(t)+E(t)+I^{+}(t)+I^{-}(t)
$$

Initially, the brand potential user group turns into OWOM communication participants of different brands at time $t$, among which $S(t)$ brand potential users are not exposed to brand OWOM information.

Based on the nature of change, the variation of brand OWOM communication participation in user groups can be segmented into two categories: encountering change and self-change (As Table 1). Encountering change is owed to the state transition arising from the encounter of two types of brand OWOM communication subjects. The self-change is the state transition caused by the enthusiasm or patience of participants themselves toward the brand activity.

Table 1. Brand OWOM communication participates in user conversion.

\begin{tabular}{|c|c|c|c|}
\hline \multirow{2}{*}{ User } & \multicolumn{2}{|c|}{ Change When Encounter with } & \multirow{2}{*}{ Self-Change } \\
\hline & Positive OWOM & Negative OWOM & \\
\hline \multirow{3}{*}{$\mathrm{S}$} & $S(i)+I^{+}(j) \stackrel{\beta_{\beta_{+}}}{\rightarrow} I^{+}(i)+I^{+}(j)$ & $S(i)+I^{-}(j) \stackrel{\beta_{S^{-}}}{\rightarrow} I^{-}(i)+I^{-}(j)$ & - \\
\hline & $S(i)+I^{+}(j) \stackrel{\alpha_{S+}}{\rightarrow} M(i)+I^{+}(j)$ & $S(i)+I^{-}(j) \stackrel{\alpha_{S^{-}}}{\rightarrow} M(i)+I^{-}(j)$ & - \\
\hline & $S(i)+I^{+}(j) \stackrel{\gamma_{S^{+}}}{\rightarrow} E(i)+I^{+}(j)$ & $S(i)+I^{-}(j) \stackrel{\gamma_{S_{-}}}{\rightarrow} E(i)+I^{-}(j)$ & - \\
\hline $\mathbf{M}$ & $M(i)+I^{+}(j) \stackrel{\beta_{M+}}{\rightarrow} I^{+}(i)+I^{+}(j)$ & $M(i)+I^{-}(j) \stackrel{\beta_{M-}^{-}}{\rightarrow} I^{-}(i)+I^{-}(j)$ & $M(i) \stackrel{\varepsilon_{M}}{\rightarrow} E(i)$ \\
\hline $\mathrm{I}^{+}$ & - & - & $I^{+}(i) \stackrel{\varepsilon_{I}}{\rightarrow} M(i)$ \\
\hline $\mathbf{I}^{-}$ & - & - & $I^{-}(i) \stackrel{\varepsilon_{\bar{I}}}{\rightarrow} M(i)$ \\
\hline
\end{tabular}


Suppose that the total number of users who select each propagation strategy within social media at time $t$ is $N$, and then:

$$
N=S(t)+I^{+}(t)+I^{-}(t)+M(t)+E(t)
$$

The individual densities of disparate users are:

$$
\begin{aligned}
s(t) & =\frac{S(t)}{N}, \\
i(t) & =\frac{I^{+}(t)}{N}, \\
\overline{\mathrm{i}}(t) & =\frac{I^{-}(t)}{N}, \\
m(t) & =\frac{M(t)}{N}, \\
e(t) & =\frac{E(t)}{N},
\end{aligned}
$$

Then, there are:

$$
s(t)+\mathrm{i}(t)+\overline{\mathrm{i}}(t)+\mathrm{m}(t)+\mathrm{e}(t)=1,
$$

The system dynamics differential equation is:

$$
\begin{aligned}
& \frac{d s(t)}{d t}=-\beta_{S^{+}}(t) i(t)-\alpha_{S^{+} S}(t) i(t)-\gamma_{S^{+} S}(t) i(t)-\beta_{S^{-}}(t) \bar{i}(t)-\alpha_{S^{-}}(t) \bar{i}(t)-\gamma_{S^{-}}(t) \bar{i}(t) \\
& \frac{d i(t)}{d t}=-\varepsilon_{I} i(t)+\beta_{S^{+}} S(t) i(t)+\beta_{M^{+}} m(t) i(t) \\
& \frac{d m(t)}{d t}=\varepsilon_{I} i(t)-\beta_{M^{+}} m(t) i(t)+\alpha_{S^{+}}(t) i(t)-\varepsilon_{M^{\prime}} m(t)+\beta_{S^{+}}(t) \bar{i}(t)-\beta_{M^{-}} m(t) \bar{i}(t) \\
& \frac{d e(t)}{d t}=\varepsilon_{M^{m}} m(t)+\varepsilon_{\bar{I}} \bar{i}(t)+\gamma_{S^{+}}(t) i(t)+\gamma_{S^{-}}(t) \bar{i}(t) \\
& \frac{d \bar{i}(t)}{d t}=-\varepsilon_{\bar{I}} \bar{i}(t)+\beta_{M^{-}} m(t) \bar{i}(t)+\beta_{S^{-}}(t) \bar{i}(t)
\end{aligned}
$$

\subsection{Evolutionary Relationship Parameters Setup}

From the differential equation, it is evident that the evolutionary relationship parameters are variables that must be fully considered in the calculation experiment. The above-mentioned parameters are about different brands of OWOM communication groups to the brand's communication effect in the whole social network. For the sake of discussion, they are divided into the following four categories in accordance with the connotation of the conversion relationship parameters (as Table 2):

(1) The acceptance index

From the perspective of OWOM communicators, this index represents their persuasive ability; from the angle of information receivers, it denotes their acceptance, perception, and recognition of OWOM.

(2) The wait-and-see index

This index represents the ability of OWOM recipients to digest information. When the brand information conveyed by the OWOM communicator satisfies the psychological expectations of potential consumers, and produces a sense of identity and empathy for the brand in those customers, the potential consumer is transformed into an OWOM messenger. OWOM spreads the information to potential consumers, which helps them further understand the brand's interest. Nevertheless, when it does not gain recognition and empathy, consumers often hesitate and intend to receive more OWOM information about the brand in social media. This will deepen their understanding of the brand. 
(3) The immune index

Responsibility of OWOM recipients (potential consumers and brand observers) on brand OWOM is inversely proportional to the acceptance factor. Thus, the higher the reception coefficient, the lower the immune coefficient.

(4) The recessionary index

This index denotes the degree of decline in OWOM communication enthusiasm. The greater the recessionary index, the faster the reputation of the OWOM communicator continues to spread the brand's OWOM information. For brand observers, the recessionary coefficient represents their patience with the acceptance of brand OWOM information. When the recessionary coefficient is larger, brand observers will be more inclined to lose patience and become immune to the brand. As a consequence, they will cease to receive any brand information.

Table 2. Evolutionary relationship parameters of the brand OWOM communication group.

\begin{tabular}{ccl}
\hline \multicolumn{1}{c}{ Types } & Parameters & \multicolumn{1}{c}{ Meaning } \\
\hline \multirow{2}{*}{ Acceptance index $\beta$} & $\beta_{S^{+}}$ & Potential customer acceptance of positive OWOM \\
& $\beta_{S^{-}}$ & Potential customer acceptance of negative OWOM \\
& $\beta_{M^{+}}$ & Brand observers' acceptance of positive OWOM \\
& $\beta_{M^{-}}$ & Brand observers' acceptance of negative OWOM \\
\hline \multirow{2}{*}{ Wait-and-see index $\alpha$} & $\alpha_{S^{+}}$ & Potential customers' view of positive OWOM \\
& $\alpha_{S^{-}}$ & Potential customers' view of negative OWOM \\
\hline \multirow{2}{*}{ Immune index $\gamma$} & $\gamma_{S^{+}}$ & Potential customers' immunity to positive OWOM \\
& $\gamma_{S^{-}}$ & Potential customers' immunity to negative OWOM \\
\hline \multirow{2}{*}{ Recessionary index $\varepsilon$} & $\varepsilon_{I}$ & Brand advocators' enthusiasm for brand promotion \\
& $\varepsilon_{\bar{I}}$ & Brand protesters deterring the brand's enthusiasm \\
& $\varepsilon_{M}$ & Brand observers' attention to the brand's patience \\
\hline
\end{tabular}

\section{Simulation and Results}

In the computational simulation, the Netlogo platform of the multi-agent-based modeling environment is selected. Netlogo is a programmable modeling environment used to simulate natural and social phenomena. It was created by Wilensy in 1999 and was developed by The Center for Connected Learning and Computer-Based Modeling, Northwestern University to date. Netlogo can control tens of thousands of individuals in parallel in modeling. It can well simulate the behaviors of micro individuals and the emergence of the macro phenomenon and reveal the relationship between them. It is suitable for simulating the behavior of complex systems.

The applicability of the platform has been verified in existing research on public opinion communication and network marketing. Different from the previous viral marketing model simulation studies, the consumer is assumed to be a static network node. This study is to describe the interactive communication behavior of social media users without restriction, and gives the simulation subject random walk attributes, that is, the agent moves randomly in the network space.

We chose the brand enterprises in the growth stage as the experimental objects. The growing brand enterprises have certain brand awareness and potential consumers, which is the most prosperous period for OWOM communication. However, consumers have a higher forgetting rate for the received information about growing brand enterprises [16]. Content research on Chinese Weibo users shows that $94 \%$ of Weibo's content is created by $5 \%$ of users, but its content is transmitted by other users [44]. Based on the investigation and survey data of Chinese Weibo [16], the positive and negative OWOM communicators in the model simulation are set as $I^{+}\left(t_{0}\right)$ versus $I^{-}\left(t_{0}\right)$. The number of users $N\left(t_{0}\right) 5 \%$ and the relevant parameters of the corresponding group evolution relationship are set as Table 3 . 
We set up six groups of simulation experiments to explore the influence of evolutionary relationship parameters' change on brand OWOM communication. In order to eliminate randomness, the result of each simulation experiment for 10 times kept the same shall prevail.

Table 3. Experimental parameter setting.

\begin{tabular}{lccccccccc}
\hline Parameter & $\boldsymbol{S}\left(\boldsymbol{t}_{0}\right)$ & $\boldsymbol{I}^{+}\left(\boldsymbol{t}_{0}\right)$ & $\boldsymbol{I}^{-}\left(\boldsymbol{t}_{0}\right)$ & $\boldsymbol{M}\left(\boldsymbol{t}_{0}\right)$ & $\boldsymbol{E}\left(\boldsymbol{t}_{0}\right)$ & $\boldsymbol{\beta}$ & $\boldsymbol{\alpha}$ & $\boldsymbol{\gamma}$ & $\boldsymbol{\varepsilon}$ \\
\hline Setting & 1350 & 50 & 50 & 300 & 150 & $(0,0.4]$ & $(0,0.5]$ & $(0.3,0.7]$ & $(0.2,0.7]$ \\
\hline
\end{tabular}

\subsection{Accepting the Impact of Index Changes on Brand Communication}

\subsubsection{Experiment 1: Consumers' Acceptance of Positive Brand OWOM}

Adjust potential consumers' acceptance index of positive OWOM information by experiments $\beta_{S^{+}}$(as shown in Table 4). Then, the variation of parameters, such as the number of positive and negative OWOM communication and the duration of the OWOM effect influence, can be obtained. The experimental results are shown in Figure 4.

Table 4. Simulation Experiment 1 parameter setting.

\begin{tabular}{ccccccccccc}
\hline $\begin{array}{c}\text { Positive OWOM } \\
\text { Acceptance Index }\end{array}$ & \multicolumn{2}{c}{$\begin{array}{c}\text { Negative OWOM } \\
\text { Acceptance Index }\end{array}$} & \multicolumn{2}{c}{$\begin{array}{c}\text { Wait -and-See } \\
\text { Index }\end{array}$} & \multicolumn{2}{c}{$\begin{array}{c}\text { Immune } \\
\text { Index }\end{array}$} & \multicolumn{2}{c}{$\begin{array}{c}\text { Recessionary } \\
\text { Index }\end{array}$} \\
\hline $\boldsymbol{\beta}_{\boldsymbol{S}^{+}}$ & $\boldsymbol{\beta}_{\boldsymbol{M}^{+}}$ & $\boldsymbol{\beta}_{\boldsymbol{S}^{-}}$ & $\boldsymbol{\beta}_{\boldsymbol{M}^{-}}$ & $\boldsymbol{\alpha}_{\boldsymbol{S}^{+}}$ & $\boldsymbol{\alpha}_{\boldsymbol{S}^{-}}$ & $\gamma_{\boldsymbol{S}^{+}}$ & $\gamma_{\boldsymbol{S}^{-}}$ & $\varepsilon_{\boldsymbol{I}}$ & $\boldsymbol{\varepsilon}_{-}$ & $\boldsymbol{\varepsilon}_{\boldsymbol{M}}$ \\
\hline 0.1 & 0.1 & 0.2 & 0.2 & 0.4 & 0.4 & 0.5 & 0.4 & 0.3 & 0.2 & 0.6 \\
0.2 & 0.2 & 0.2 & 0.2 & 0.3 & 0.4 & 0.5 & 0.4 & 0.3 & 0.2 & 0.6 \\
0.3 & 0.3 & 0.2 & 0.2 & 0.2 & 0.4 & 0.5 & 0.4 & 0.3 & 0.2 & 0.6 \\
0.4 & 0.4 & 0.2 & 0.2 & 0.1 & 0.4 & 0.5 & 0.4 & 0.3 & 0.2 & 0.6 \\
\hline
\end{tabular}

Figure 4a signifies that positive brand-of-mouth information is gradually accepted by potential consumers, that is, the persuasive ability of brand advocators is improved bit by bit. In the whole cycle of brand OWOM communication, the number of brand advocators increased as a whole during the brand communication cycle, and the individual maximum increased remarkably; the number of brand resistance decreased overall.

It can be seen from Figure $4 \mathrm{~b}$ that the persistence of the brand's positive OWOM effect increases with the rise in the level of positive OWOM received by potential consumers, that is, it will go up as the persuasive ability of brand advocators increases. With respect to the influence of the negative OWOM effect, the durability is reduced as the persuasive ability of brand advocators increases.

From OWOM recipients, the experimental results show that the increasing acceptance of positive OWOM information by potential consumers reinforces the spread of positive OWOM, but has a specific inhibitory effect on the spread of negative OWOM. For OWOM communicators, brand advocators with strong communication ability can not only promote the brand but also reduce the spread of brand negative OWOM. Besides, they enhance the brand in social media from both positive and negative aspects. Images are listed below: 


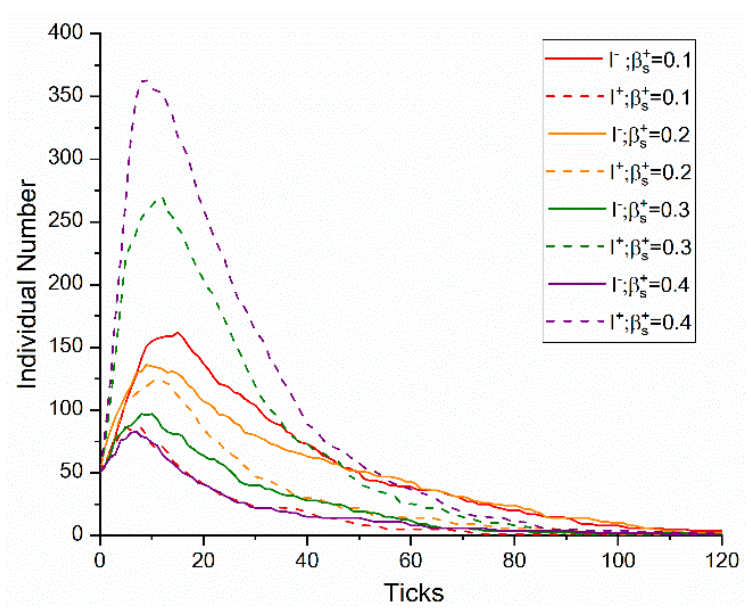

(a)

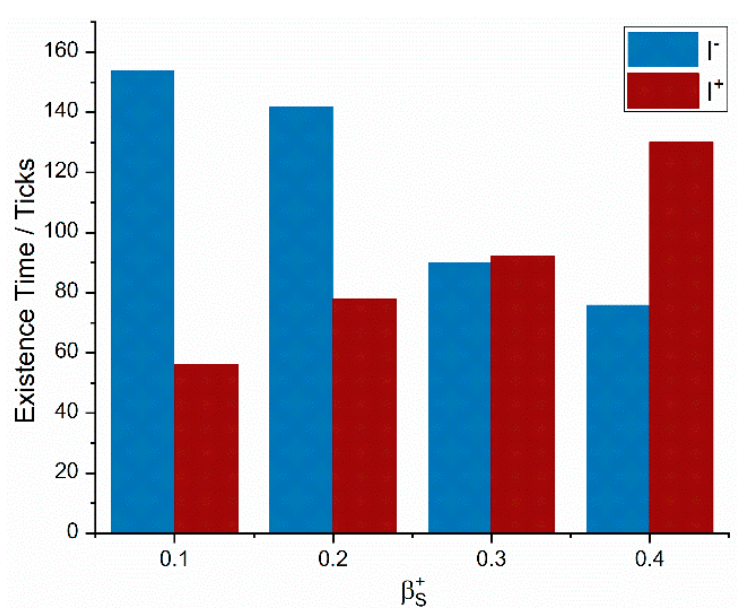

(b)

Figure 4. OWOM communication effect when the positive OWOM acceptance index is different. (a) The individual number of brand advocators and protesters; (b) the existence time of positive and negative OWOM.

\subsubsection{Experiment 2: Consumers' Acceptance of Negative Brand OWOM}

Adjust the acceptance index of negative OWOM information by potential consumers via experiments $\beta_{S^{-}}$(as shown in Table 5). The changes in parameters, such as the number of positive and negative OWOM communication and the persistent period of influence of the OWOM effect, can be acquired. The experimental results are shown in Figure 5.

Table 5. Simulation Experiment 2 parameter setting.

\begin{tabular}{|c|c|c|c|c|c|c|c|c|c|c|}
\hline \multicolumn{2}{|c|}{$\begin{array}{l}\text { Positive OWOM } \\
\text { Acceptance Index }\end{array}$} & \multicolumn{2}{|c|}{$\begin{array}{l}\text { Negative OWOM } \\
\text { Acceptance Index }\end{array}$} & \multicolumn{2}{|c|}{$\begin{array}{l}\text { Wait-and-See } \\
\text { Index }\end{array}$} & \multicolumn{2}{|c|}{$\begin{array}{l}\text { Immune } \\
\text { Index }\end{array}$} & \multicolumn{3}{|c|}{$\begin{array}{l}\text { Recessionary } \\
\text { Index }\end{array}$} \\
\hline$\beta_{S^{+}}$ & $\beta_{M^{+}}$ & $\beta_{S^{-}}$ & $\beta_{M^{-}}$ & $\alpha_{S^{+}}$ & $\alpha_{S^{-}}$ & $\gamma_{S^{+}}$ & $\gamma_{S^{-}}$ & $\varepsilon_{I}$ & $\mathcal{E}_{I}^{-}$ & $\varepsilon_{M}$ \\
\hline 0.2 & 0.2 & 0.1 & 0.1 & 0.3 & 0.5 & 0.5 & 0.4 & 0.3 & 0.2 & 0.6 \\
\hline 0.2 & 0.2 & 0.2 & 0.2 & 0.3 & 0.4 & 0.5 & 0.4 & 0.3 & 0.2 & 0.6 \\
\hline 0.2 & 0.2 & 0.3 & 0.3 & 0.3 & 0.3 & 0.5 & 0.4 & 0.3 & 0.2 & 0.6 \\
\hline 0.2 & 0.2 & 0.4 & 0.4 & 0.3 & 0.2 & 0.5 & 0.4 & 0.3 & 0.2 & 0.6 \\
\hline
\end{tabular}

In Figure 5a, it is obvious that potential consumers' increasing acceptance of negative OWOM information reflects the growth of the brand persuader's persuasive ability. In the brand OWOM communication cycle, the number of brand protesters is increasing and the individual maximums are experiencing a leap forward, while the number of brand advocators is decreasing on the whole. Furthermore, the stronger the persuasion of brand resistance, the more obvious the number of brand advocators is weakened.

From Figure $5 \mathrm{~b}$, we can see that the persistence of the negative OWOM effect influence increases with the rising degree of negative OWOM received by potential consumers. In other words, as the persuasion ability of brand resistance increases, the influence persistence of positive OWOM effect lessens.

In the eyes of OWOM recipients, the increasing acceptance of brand negative OWOM information by potential consumers has a strengthening effect on the spread of brand negative OWOM, but restrains the spread of positive OWOM to a certain extent. As for OWOM communicators, they believe that brand-responders with strong communication ability can reduce brand image, its positive OWOM communication, and positive brand promotion efficiency. Moreover, the brand, in social aspects, will be damaged from both positive and negative aspects. The image in the media is as follows. 


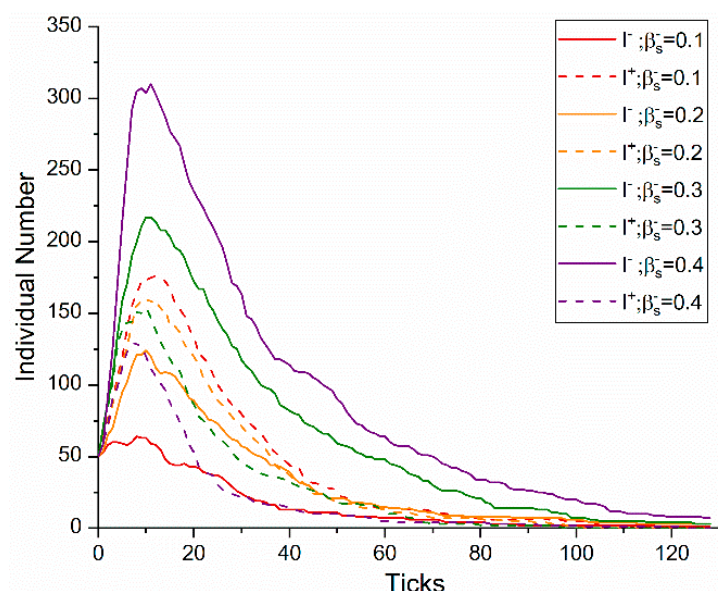

(a)

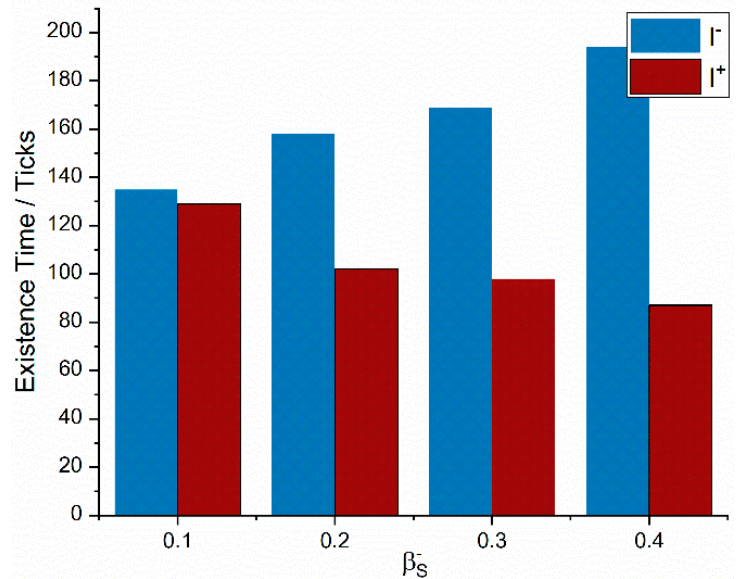

(b)

Figure 5. OWOM communication effect when the negative OWOM acceptance index is different. (a) The individual number of brand advocators and protesters; (b) the existence time of positive and negative OWOM.

\subsection{Impact of Changes in the Immune Index on Brand Communication}

\section{Experiment 3: Consumers' Immunity to the Positive and Negative Brand OWOM}

After adjustment of the potential consumer's immune index to the positive and negative brand OWOM through experiments $\gamma_{S^{+}}, \gamma_{S^{-}}$(as shown in Table 6), the changes in parameters like the positive and negative OWOM communication number and the duration of the influence of the OWOM effect can be obtained. The experimental results are shown in Figure 6.

Table 6. Simulation Experiment 3 parameter setting.

\begin{tabular}{|c|c|c|c|c|c|c|c|c|c|c|c|}
\hline & \multicolumn{2}{|c|}{$\begin{array}{l}\text { Positive OWOM } \\
\text { Acceptance Index }\end{array}$} & \multicolumn{2}{|c|}{$\begin{array}{l}\text { Negative OWOM } \\
\text { Acceptance Index }\end{array}$} & \multicolumn{2}{|c|}{$\begin{array}{l}\text { Wait-and-See } \\
\text { Index }\end{array}$} & \multicolumn{2}{|c|}{$\begin{array}{l}\text { Immune } \\
\text { Index }\end{array}$} & \multicolumn{3}{|c|}{$\begin{array}{l}\text { Recessionary } \\
\text { Index }\end{array}$} \\
\hline & $\beta_{S^{+}}$ & $\beta_{M^{+}}$ & $\beta_{S^{-}}$ & $\beta_{M^{-}}$ & $\alpha_{S^{+}}$ & $\alpha_{S^{-}}$ & $\gamma_{S^{+}}$ & $\gamma_{S^{-}}$ & $\varepsilon_{I}$ & $\mathcal{E}_{I}^{-}$ & $\varepsilon_{M}$ \\
\hline \multirow{4}{*}{1} & 0.2 & 0.2 & 0.2 & 0.2 & 0.2 & 0.2 & 0.6 & 0.6 & 0.3 & 0.2 & 0.6 \\
\hline & 0.2 & 0.2 & 0.2 & 0.2 & 0.3 & 0.3 & 0.5 & 0.5 & 0.3 & 0.2 & 0.6 \\
\hline & 0.2 & 0.2 & 0.2 & 0.2 & 0.4 & 0.4 & 0.4 & 0.4 & 0.3 & 0.2 & 0.6 \\
\hline & 0.2 & 0.2 & 0.2 & 0.2 & 0.5 & 0.5 & 0.3 & 0.3 & 0.3 & 0.2 & 0.6 \\
\hline \multirow{4}{*}{2} & 0.2 & 0.2 & 0.2 & 0.2 & 0.2 & 0.2 & 0.6 & 0.6 & 0.3 & 0.2 & 0.6 \\
\hline & 0.2 & 0.2 & 0.2 & 0.2 & 0.2 & 0.3 & 0.6 & 0.5 & 0.3 & 0.2 & 0.6 \\
\hline & 0.2 & 0.2 & 0.2 & 0.2 & 0.2 & 0.4 & 0.6 & 0.4 & 0.3 & 0.2 & 0.6 \\
\hline & 0.2 & 0.2 & 0.2 & 0.2 & 0.2 & 0.5 & 0.6 & 0.3 & 0.3 & 0.2 & 0.6 \\
\hline \multirow{4}{*}{3} & 0.2 & 0.2 & 0.2 & 0.2 & 0.2 & 0.2 & 0.6 & 0.6 & 0.3 & 0.2 & 0.6 \\
\hline & 0.2 & 0.2 & 0.2 & 0.2 & 0.3 & 0.2 & 0.5 & 0.6 & 0.3 & 0.2 & 0.6 \\
\hline & 0.2 & 0.2 & 0.2 & 0.2 & 0.4 & 0.2 & 0.4 & 0.6 & 0.3 & 0.2 & 0.6 \\
\hline & 0.2 & 0.2 & 0.2 & 0.2 & 0.5 & 0.2 & 0.3 & 0.6 & 0.3 & 0.2 & 0.6 \\
\hline
\end{tabular}

In Figure $6 a$, the potential immunity of the potential consumers to the positive and negative brand OWOM is identical. When the immunity becomes lower, the peak number of brand-responders and brand advocators is larger (the peak number of brand-responders is usually larger than that of brand advocators). Figure $6 \mathrm{~b}$ shows that with the year-on-year alteration of potential consumer's immunity to the positive and negative brand OWOM, the persistence of the positive and negative OWOM effect does not eminently vary in accordance with the law. 
It is observed from Figure $6 \mathrm{c}, \mathrm{d}$ that only if potential consumers are immune to negative brand OWOM, there is no change in the number of brand advocators and protesters, and the persistence of positive and negative OWOM effects is also unvaried. It clearly conforms to the changes in the law.

From Figure 6e,f, only when the potential consumer's immunity to positive brand OWOM is gradually reduced, can the number of brand advocators at the peak increase, while the number of brand protesters and the persistence of positive and negative OWOM effects have no apparent and regular change.

The experimental results show that when the potential consumers have the same immunizing power to the positive and negative brand OWOM, the negative OWOM spreads more widely than the positive one, signifying that the brand OWOM communication is more affected by negative OWOM. When potential consumers have different immunity to positive and negative OWOM, consumers' positive immunity to positive OWOM and the coverage of the brand's positive OWOM communication are correspondingly reduced. Furthermore, the breadth of the brand's negative OWOM spread is partly improved, but the degree of influence is still weak.

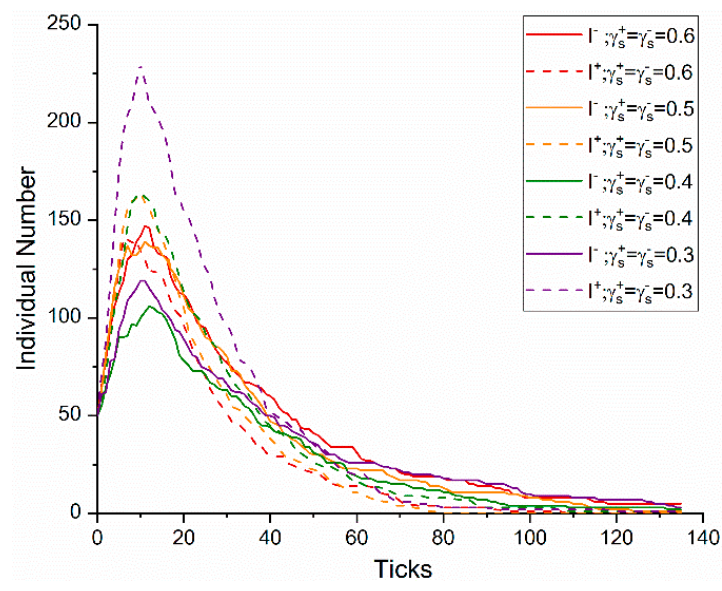

(a)

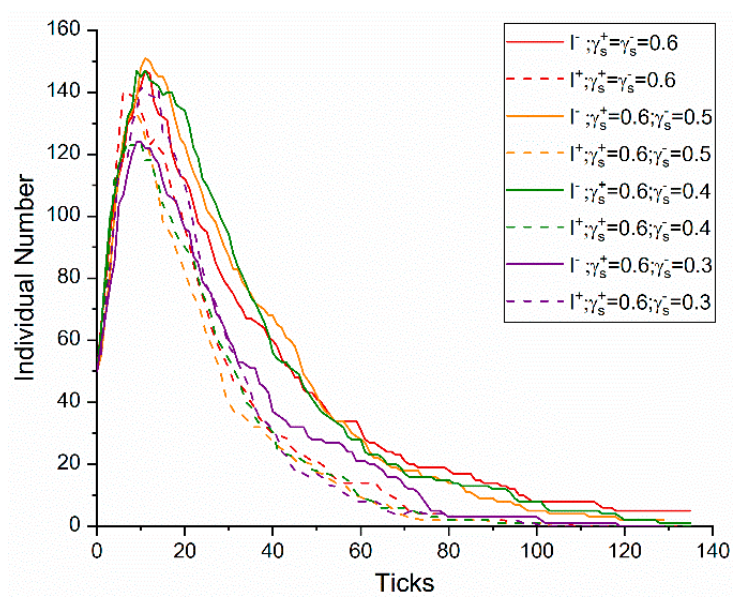

(c)

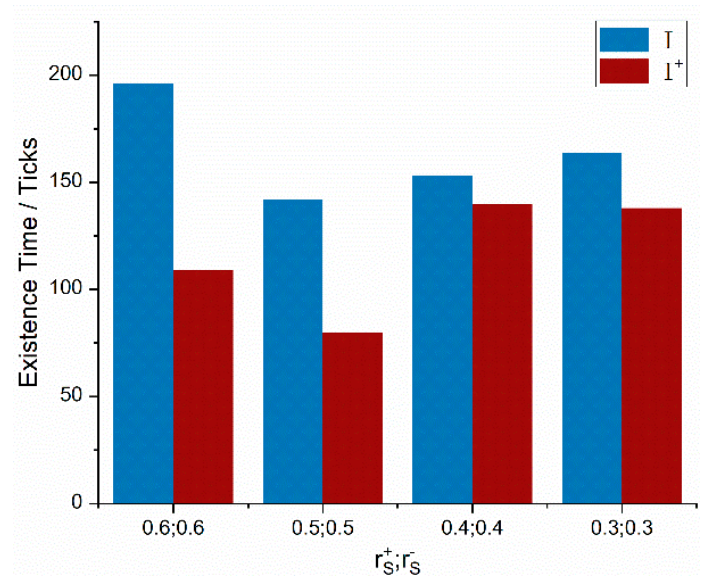

(b)

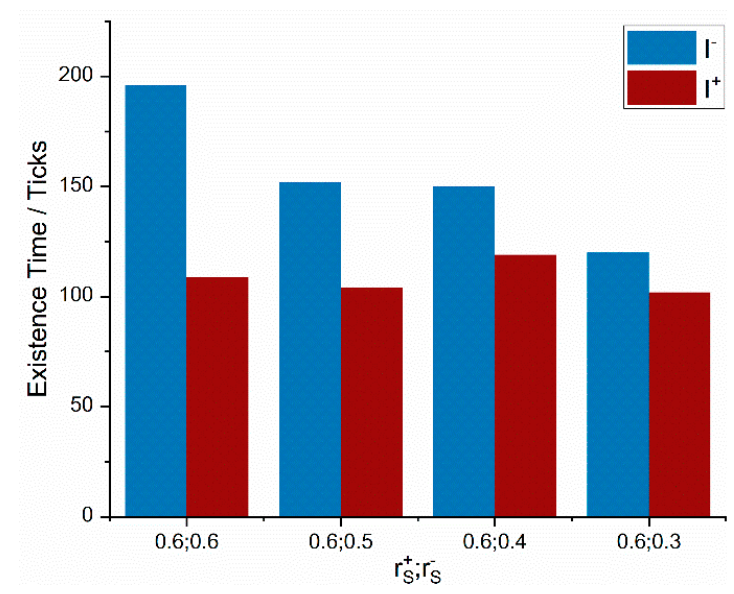

(d)

Figure 6. Cont. 


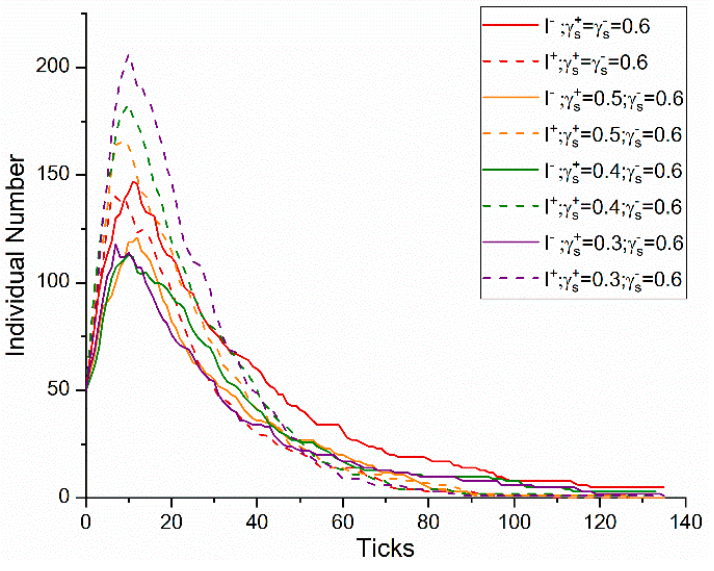

(e)

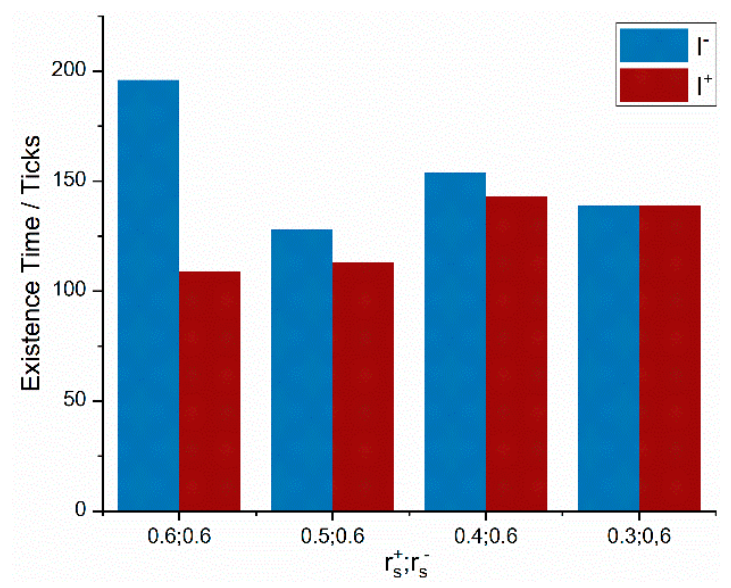

(f)

Figure 6. Brand OWOM communication effect when the positive and negative OWOM immune conditions are different. (a) The individual number of brand advocators and protesters (with $\alpha_{S^{+}}, \alpha_{S^{-}}$, $\gamma_{S^{+}}, \gamma_{S^{-}}$changing); (b) the existence time of positive and negative OWOM (with $\alpha_{S^{+}}, \alpha_{S^{-}}, \gamma_{S^{+}}, \gamma_{S^{-}}$ changing); (c) the individual number of brand advocators and protesters (with $\alpha_{S^{-}}, \gamma_{S^{-}}$changing); (d) the existence time of positive and negative OWOM (with $\alpha_{S^{-}}, \gamma_{S^{-}}$changing); (e) the individual number of brand advocators and protesters (with $\alpha_{S^{+}}, \gamma_{S^{+}}$changing); (f) the existence time of positive and negative OWOM (with $\alpha_{S^{+}}, \gamma_{S^{+}}$changing).

\subsection{Impact of Changes in the Recessionary Index on Brand OWOM Communication}

\subsubsection{Experiment 4: Changes in the Spread of Brand Advocators}

In terms of the brand advocators' recessionary index, make an adjustment through experiments $\varepsilon_{I}$ (as shown in Table 7). Parametric variation, such as the positive and negative OWOM communication amount and the duration of the influence of the OWOM effect, can be obtained. The experimental results are shown in Figure 7.

Table 7. Simulation Experiment 4 parameter setting.

\begin{tabular}{ccccccccccc}
\hline $\begin{array}{c}\text { Positive OWOM } \\
\text { Acceptance Index }\end{array}$ & \multicolumn{2}{c}{$\begin{array}{c}\text { Negative OWOM } \\
\text { Acceptance Index }\end{array}$} & \multicolumn{2}{c}{$\begin{array}{c}\text { Wait-and-See } \\
\text { Index }\end{array}$} & \multicolumn{2}{c}{$\begin{array}{c}\text { Immune } \\
\text { Index }\end{array}$} & \multicolumn{2}{c}{$\begin{array}{c}\text { Recessionary } \\
\text { Index }\end{array}$} \\
\hline $\boldsymbol{\beta}_{\boldsymbol{S}^{+}}$ & $\boldsymbol{\beta}_{\boldsymbol{M}^{+}}$ & $\boldsymbol{\beta}_{\boldsymbol{S}^{-}}$ & $\boldsymbol{\beta}_{\boldsymbol{M}^{-}}$ & $\boldsymbol{\alpha}_{\boldsymbol{S}^{+}}$ & $\boldsymbol{\alpha}_{\boldsymbol{S}^{-}}$ & $\gamma_{S^{+}}$ & $\gamma_{\boldsymbol{S}^{-}}$ & $\boldsymbol{\varepsilon}_{\boldsymbol{I}}$ & $\boldsymbol{\varepsilon}^{-}$ & $\boldsymbol{\varepsilon}_{\boldsymbol{M}}$ \\
\hline 0.2 & 0.2 & 0.3 & 0.3 & 0.3 & 0.4 & 0.5 & 0.4 & 0.2 & 0.2 & 0.6 \\
0.2 & 0.2 & 0.3 & 0.3 & 0.3 & 0.4 & 0.5 & 0.4 & 0.3 & 0.2 & 0.6 \\
0.2 & 0.2 & 0.3 & 0.3 & 0.3 & 0.4 & 0.5 & 0.4 & 0.4 & 0.2 & 0.6 \\
0.2 & 0.2 & 0.3 & 0.3 & 0.3 & 0.4 & 0.5 & 0.4 & 0.5 & 0.2 & 0.6 \\
\hline
\end{tabular}

As shown in Figure 7a, as the brand advocators' recessionary index increases, the brand advocators' enthusiasm for positive OWOM communication decreases steadily, the number of brand advocators drops significantly during the brand communication cycle, and the group peaks. The rate of descent has increased dramatically. In addition, the number of brand protesters did not markedly fluctuate in line with the law.

As illustrated in Figure $7 \mathrm{~b}$, the persistence of the influence of the positive OWOM effect decreases with the increase of the brand advocator's recessionary index. Nevertheless, the persistence of the impact of the negative one has no visible regular changes.

The experimental results show that the increase of brand advocators' recessionary index has suppressed the brand's positive OWOM transmission, and will accelerate the decay rate of brand advocators. However, there is no eminent influence on the brand's negative OWOM transmission. 
The decline of brand advocators has weakened the brand's positive OWOM spread, reducing its positive brand promotion efficiency. In contrast, it does not affect the long-term spread of negative OWOM.

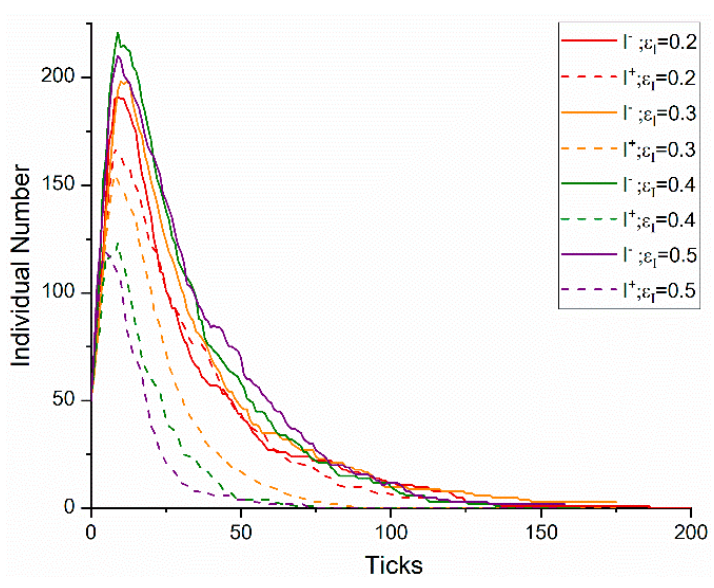

(a)

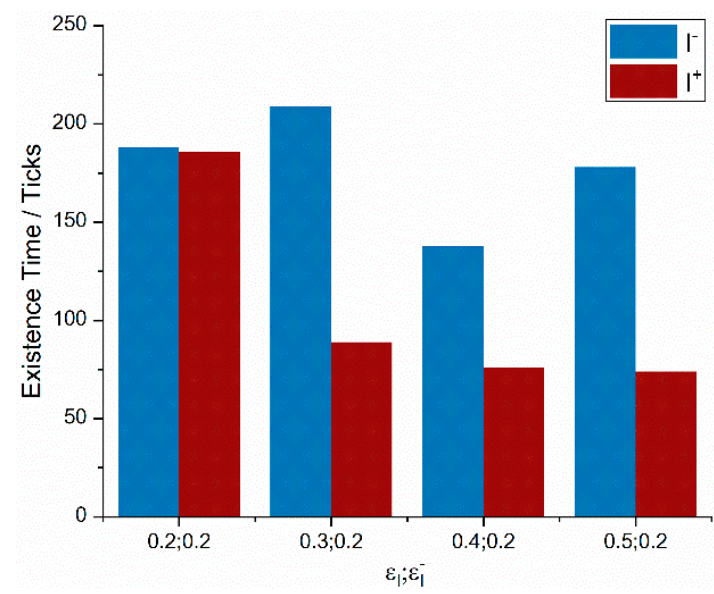

(b)

Figure 7. Brand OWOM communication effect when the brand advocators' recessionary conditions are different. (a) The individual number of brand advocators and protesters; (b) the existence time of positive and negative OWOM.

\subsubsection{Experiment 5: Changes in the Recession of Brand Protesters}

Adjust the brand protesters' recessionary index via the experimentation $\varepsilon_{\bar{I}}$ (as shown in Table 8 ), and we can get the changes in parameters, such as the number of positive and negative OWOM communication and the duration of the influence of the OWOM effect. The experimental results are illustrated in Figure 8.

Table 8. Simulation Experiment 5 parameter setting.

\begin{tabular}{ccccccccccc}
\hline $\begin{array}{c}\text { Positive OWOM } \\
\text { Acceptance Index }\end{array}$ & \multicolumn{2}{c}{$\begin{array}{c}\text { Negative OWOM } \\
\text { Acceptance Index }\end{array}$} & \multicolumn{2}{c}{$\begin{array}{c}\text { Wait-and-See } \\
\text { Index }\end{array}$} & \multicolumn{2}{c}{$\begin{array}{c}\text { Immune } \\
\text { Index }\end{array}$} & \multicolumn{2}{c}{$\begin{array}{c}\text { Recessionary } \\
\text { Index }\end{array}$} \\
\hline $\boldsymbol{\beta}_{\boldsymbol{S}^{+}}$ & $\boldsymbol{\beta}_{\boldsymbol{M}^{+}}$ & $\boldsymbol{\beta}_{\boldsymbol{S}^{-}}$ & $\boldsymbol{\beta}_{\boldsymbol{M}^{-}}$ & $\boldsymbol{\alpha}_{\boldsymbol{S}^{+}}$ & $\boldsymbol{\alpha}_{\boldsymbol{S}^{-}}$ & $\boldsymbol{\gamma}_{\boldsymbol{S}^{+}}$ & $\boldsymbol{\gamma}_{\boldsymbol{S}^{-}}$ & $\boldsymbol{\varepsilon}_{\boldsymbol{I}}$ & $\boldsymbol{\varepsilon}_{\boldsymbol{I}}$ & $\boldsymbol{\varepsilon}_{\boldsymbol{M}}$ \\
\hline 0.2 & 0.2 & 0.3 & 0.3 & 0.3 & 0.4 & 0.5 & 0.4 & 0.3 & 0.2 & 0.6 \\
0.2 & 0.2 & 0.3 & 0.3 & 0.3 & 0.4 & 0.5 & 0.4 & 0.3 & 0.3 & 0.6 \\
0.2 & 0.2 & 0.3 & 0.3 & 0.3 & 0.4 & 0.5 & 0.4 & 0.3 & 0.4 & 0.6 \\
0.2 & 0.2 & 0.3 & 0.3 & 0.3 & 0.4 & 0.5 & 0.4 & 0.3 & 0.5 & 0.6 \\
\hline
\end{tabular}

In Figure 8a, with the increase of the brand protesters' recessionary index, the level of popularity about negative resistance of brand protesters is gradually decreasing, and its quantity is apt to lessen in the brand communication cycle, but the trend is not obvious. Moreover, the change in the number of brand advocators is unapparent.

As shown in Figure 8b, the persistence of the influence of the negative OWOM effect distinctly diminishes with the increase of the brand recessionary index, while the persistence of the positive one has no prominent regular changes.

The experimental results show that the increase of brand resistance index and the declining index simply exerts a certain inhibitory influence on the spread of brand negative OWOM and the durability of brand negative OWOM effect, but has no conspicuous influence on the brand's positive OWOM communication. 


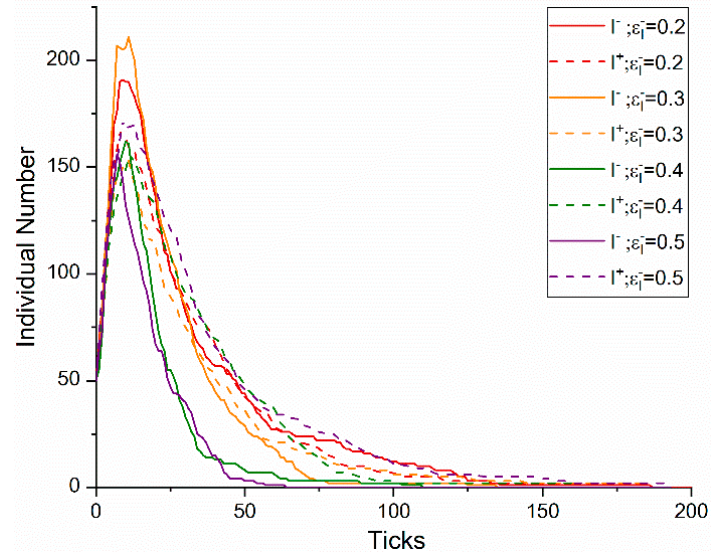

(a)

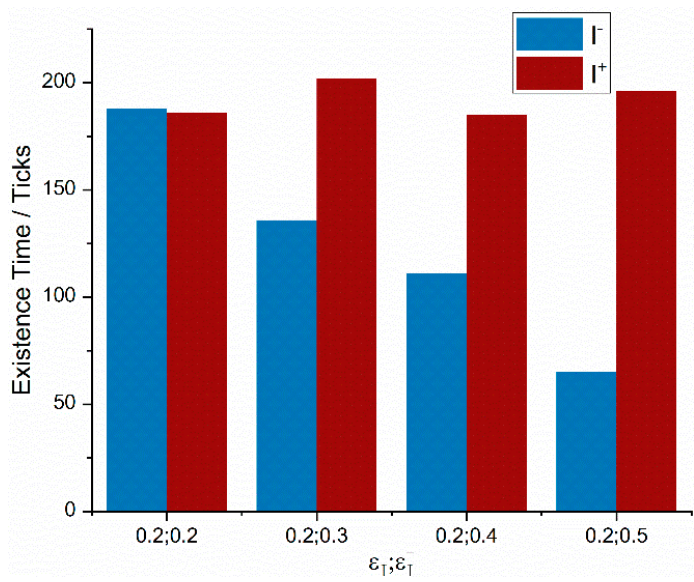

(b)

Figure 8. Brand OWOM communication effect when the brand protesters' recessionary conditions are different. (a) The individual number of brand advocators and protesters; (b) the existence time of positive and negative OWOM.

\subsubsection{Experiment 6: Changes in the Recession of Brand Observers}

By adjusting the brand observers' recessionary index through experimentation $\varepsilon_{M}$ (as shown in Table 9), the variation in parameters, such as the number of positive and negative OWOM communication and the duration of the influence of the OWOM effect, can be obtained. The experimental results are shown in Figure 9.

Table 9. Simulation Experiment 6 parameter setting.

\begin{tabular}{ccccccccccc}
\hline $\begin{array}{c}\text { Positive OWOM } \\
\text { Acceptance Index }\end{array}$ & \multicolumn{2}{c}{$\begin{array}{c}\text { Negative OWOM } \\
\text { Acceptance Index }\end{array}$} & \multicolumn{2}{c}{$\begin{array}{c}\text { Wait-and-See } \\
\text { Index }\end{array}$} & \multicolumn{2}{c}{$\begin{array}{c}\text { Immune } \\
\text { Index }\end{array}$} & \multicolumn{2}{c}{$\begin{array}{c}\text { Recessionary } \\
\text { Index }\end{array}$} \\
\hline $\boldsymbol{\beta}_{\boldsymbol{S}^{+}}$ & $\boldsymbol{\beta}_{\boldsymbol{M}^{+}}$ & $\boldsymbol{\beta}_{\boldsymbol{S}^{-}}$ & $\boldsymbol{\beta}_{\boldsymbol{M}^{-}}$ & $\boldsymbol{\alpha}_{\boldsymbol{S}^{+}}$ & $\boldsymbol{\alpha}_{\boldsymbol{S}^{-}}$ & $\boldsymbol{\gamma}_{S^{+}}$ & $\boldsymbol{\gamma}_{\boldsymbol{S}^{-}}$ & $\boldsymbol{\varepsilon}_{\boldsymbol{I}}$ & $\boldsymbol{\varepsilon}_{\boldsymbol{I}}$ & $\boldsymbol{\varepsilon}_{\boldsymbol{M}}$ \\
\hline 0.2 & 0.2 & 0.3 & 0.3 & 0.3 & 0.4 & 0.5 & 0.4 & 0.3 & 0.2 & 0.2 \\
0.2 & 0.2 & 0.3 & 0.3 & 0.3 & 0.4 & 0.5 & 0.4 & 0.3 & 0.2 & 0.3 \\
0.2 & 0.2 & 0.3 & 0.3 & 0.3 & 0.4 & 0.5 & 0.4 & 0.3 & 0.2 & 0.4 \\
0.2 & 0.2 & 0.3 & 0.3 & 0.3 & 0.4 & 0.5 & 0.4 & 0.3 & 0.2 & 0.5 \\
\hline
\end{tabular}

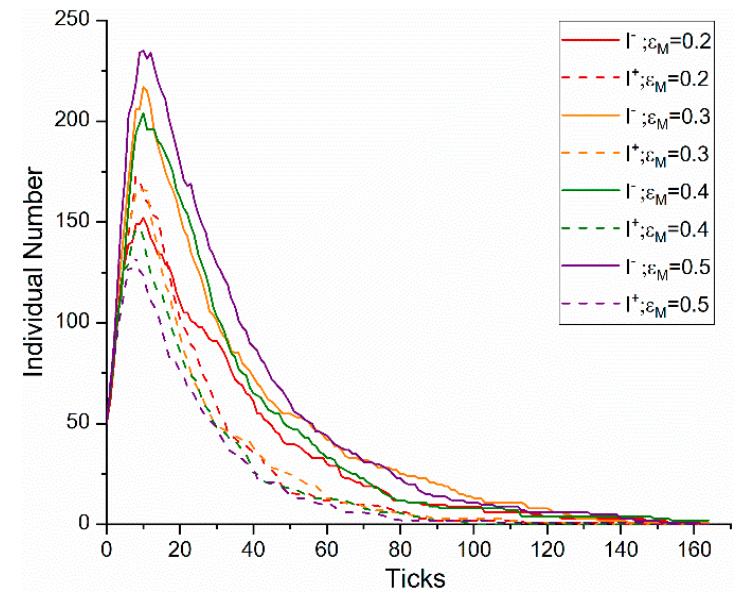

(a)

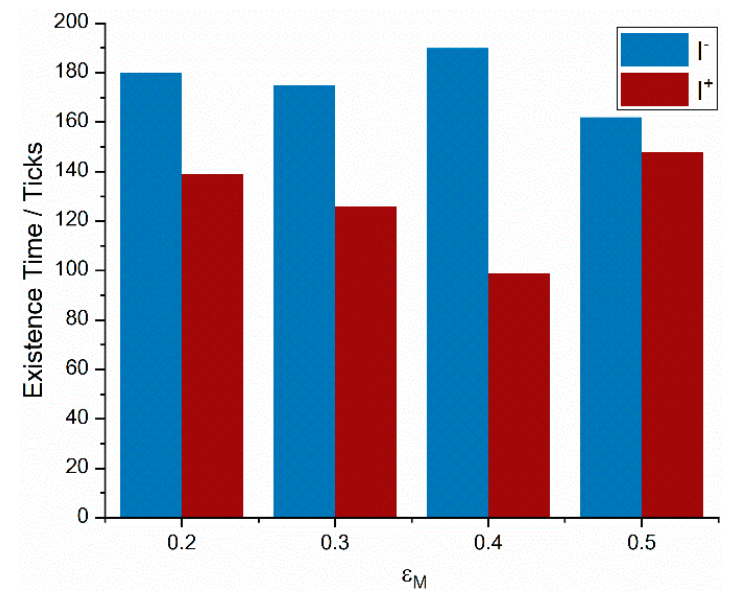

(b)

Figure 9. Brand OWOM communication effect when the brand observers' recessionary conditions are different. (a) The individual number of brand advocators and protesters; (b) the existence time of positive and negative OWOM. 
In Figure 9, the brand observer's recessionary index means that the willingness of brand observers to continue to accept brand information. When it is gradually reduced, there is no significant alteration in the number of brand advocators and brand protesters; heterogeneous OWOM effect has a lasting influence. There lacks noticeable regular change.

The experimental results display that the long-range patience of the brand's wait-and-see attitude does not impact the spread of brand OWOM regularly.

\section{Conclusions and Prospects}

To explore the influence of heterogeneous brand OWOM on brand communication, we analyze the evolution process of the social media brand OWOM communication group in line with SOR theory. As a new virus, the brand negative OWOM is also integrated into the traditional viral marketing model, and the social network is profoundly analyzed. In the dynamic process of OWOM communication among consumers, we constructed the heterogeneous OWOM communication model of the brand network covering five types of brand OWOM communication groups and four sorts of group evolution coefficients. Based on the experience and actual data of existing brand marketing related simulation research, the simulation parameters were set, and the multi-agent-based simulation with six types of scenarios and 28 sets of sub-experiments was designed and implemented. The results offer the following strategies for brand enterprises to optimize social media brand promotion strategies. Reference value:

(1) The brand satisfaction of online opinion leaders should be paid attention to. The persuasive ability of brand advocators and brand protesters influences the heterogeneous OWOM of brands in social media in a different way. However, opinion leaders like the influencer in social media often have sound influence and persuasiveness, so that they are easy to obtain consumers. The trust of brand companies can improve the satisfaction of opinion leaders on the brand in social media, thus enhancing their brand's online reputation and promotion efficiency.

(2) Pay attention to the control of negative OWOM communication. When potential consumers have lower brand and OWOM immunity, the perception of the brand is more affected by negative OWOM. What is worse, the negative OWOM information spreads more widely within the group. That is to say, when the consumer market has a high degree of acceptance of brand information, brand enterprises should focus more on controlling and intervening in the negative evaluation of OWOM, so as to avoid further deterioration of brand images in social media.

(3) Maintaining the enthusiasm of brand advocators should be taken into account. Thanks to the spread enthusiasm of brand heterosexual OWOM communicators, the breadth and durability of brand heterogeneous OWOM communication are affected. The wait-and-see attitude of consumers' patience and high level, however, cannot significantly affect the brand OWOM communication effect. Therefore, brand enterprises can identify the cycle of brand communication heat decline. By timely holding brand marketing promotion activities with various forms and enhancing brand loyal customer experience, corporations can thereby enhance the communication enthusiasm of brand advocators and the durability of brand OWOM communication.

The conclusion of this study confirms the viewpoints of the literature [5-7], but for the first time reveals the quantitative relationship among the acceptance index, wait-and-see index, immune index, recessionary index, and the OWOM communication effect through the method of viral marketing simulation based on SOR theoretical framework. Based on the conclusion of this study, it is suggested that brand enterprises should pay more attention to take three different strategies to deal with three groups: (1) For opinion leaders, enterprises should focus on improving their brand satisfaction and form a positive OWOM to inhibit the negative sound. (2) For the wait-and-see group and potential consumers, enterprises should maintain the popularity of the positive OWOM since the negative OWOM spreads fast in a neutral environment. (3) The negative OWOM must be held by strong public relations activities tactically and by steady improvement of products and services strategically.

Based on the multi-agent-based simulation research, the dynamic evolution law of brand heterogeneous OWOM effect in social media is reflected to a certain extent. However, the research 
still has some drawbacks: (1) Model limitation. Real communication networks always have scale-free characteristics and high cluster coefficient. Due to the constraints of the model simplification, it is still using a random walk interact framework and fails to completely break the deviation between computer simulation and real situation. (2) Media channel simplification. In the future, the brand communication channel can be further expanded to the integrated media channel to explore the communication mechanism of a multi-channel brand reputation.

Author Contributions: Conceptualization, M.L.; methodology, L.Q.; software, M.L.; validation, J.Z.; writing—original draft preparation, M.L.; writing-review and editing, L.Q. and J.Z. All authors have read and agreed to the published version of the manuscript.

Funding: This research was funded by the National Key R\&D Program of China (2017YFB1400500).

Acknowledgments: The authors are grateful to the anonymous reviewers and the editor for their valuable comments and suggestions that have greatly improved the quality of this paper.

Conflicts of Interest: The authors declare no conflicts of interest.

\section{References}

1. Anderson, E.W. Customer Satisfaction and Word of Mouth. J. Serv. Res. 1998, 1, 5-17. [CrossRef]

2. Ajorlou, A.; Jadbabaie, A.; Kakhbod, A. Dynamic Pricing in Social Networks: The Word-of-Mouth Effect. Manag. Sci. 2018, 64, 971-979. [CrossRef]

3. Chu, S.C.; Kim, Y. Determinants of Consumer Engagement in Electronic Word-of-Mouth (Ewom) in Social Networking Sites. Int. J. Advert. 2011, 30, 47. [CrossRef]

4. Phelps, J.E.; Lewis, R.; Mobilio, L.; Perry, D.; Raman, N. Viral Marketing or Electronic Word-of-Mouth Advertising: Examining Consumer Responses and Motivations to Pass Along Email. J. Advert. Res. 2004, 44, 333-348. [CrossRef]

5. Herr, P.M.; Kardes, F.R.; Kim, J. Effects of Word-of-Mouth and Product-Attribute Information on Persuasion: An Accessibility-Diagnosticity Perspective. J. Consum. Res. 1991, 17, 454-462. [CrossRef]

6. Cheung, C.M.; Lee, M.K.; Rabjohn, N. The Impact of Electronic Word-of-Mouth-the Adoption of Online Opinions in Online Customer Communities. Internet Res. 2008, 18, 229-247. [CrossRef]

7. Balaji, M.S.; Khong, K.W.; Chong, A.Y. Determinants of Negative Word-of-Mouth Communication Using Social Networking Sites. Inf. Manag. 2016, 53, 528-540. [CrossRef]

8. Lee, J.; Park, D.H.; Han, I. The Effect of Negative Online Consumer Reviews on Product Attitude: An Information Processing View. Electron. Commer. Res. Appl. 2008, 7, 341-352. [CrossRef]

9. Tsao, H.Y.; Chen, M.Y.; Lin, H.C.; Ma, Y.C. The Asymmetric Effect of Review Valence on Numerical Rating a Viewpoint from a Sentiment Analysis of Users of Tripadvisor. Online Inf. Rev. 2019, 43, 283-300. [CrossRef]

10. Laczniak, R.N.; DeCarlo, T.E.; Ramaswami, S.N. Consumers' Responses to Negative Word-of-Mouth Communication: An Attribution Theory Perspective. J. Consum. Psychol. 2001, 11, 57-73. [CrossRef]

11. De Bruyn, A.; Lilien, G.L. A Multi-Stage Model of Word-of-Mouth Influence through Viral Marketing. Int. J. Res. Mark. 2008, 25, 151-163. [CrossRef]

12. Wang, J.; Wang, X.; Li, Y. A Discrete Electronic Word-of-Mouth Propagation Model and Its Application in Online Social Networks. Phys. Stat. Mech. Appl. 2019, 527, 121172. [CrossRef]

13. Roy, S.K.; Butaney, G.; Sekhon, H.; Butaney, B. Word-of-Mouth and Viral Marketing Activity of the on-Line Consumer: The Role of Loyalty Chain Stages Theory. J. Strateg. Mark. 2014, 22, 494-512. [CrossRef]

14. Van der Lans, R.; Van Bruggen, G.; Eliashberg, J.; Wierenga, B. A Viral Branching Model for Predicting the Spread of Electronic Word of Mouth. Mark. Sci. 2010, 29, 348-365. [CrossRef]

15. Feng, J.; Liu, B. Dynamic Impact of Online Word-of-Mouth and Advertising on Supply Chain Performance. Int. J. Environ. Res. Public Health 2018, 15, 69. [CrossRef] [PubMed]

16. Wang, Z.; Hong, Z.; Gang, Z.; Jian, Z. An Acp-Based Approach for Complex Social Network Marketing System. Syst. Eng. Theory Pract. 2017, 37, 2897-2907.

17. Liu, W.; Li, T.; Liu, X.; Xu, H. Spreading Dynamics of a Word-of-Mouth Model on Scale-Free Networks. IEEE Access 2018, 6, 65563-65572. [CrossRef]

18. Kvasnicka, M. Viral Video Diffusion in a Fixed Social Network: An Agent-Based Model. Procedia Econ. Financ. 2014, 12, 334-342. [CrossRef] 
19. Ferguson, R. Word of Mouth and Viral Marketing: Taking the Temperature of the Hottest Trends in Marketing. J. Consum. Mark. 2008, 25, 179-182. [CrossRef]

20. Goncalves, J.N.C.; Rodrigues, H.S.; Monteiro, M.T.T. A Contribution of Dynamical Systems Theory and Epidemiological Modeling to a Viral Marketing Campaign. Intell. Syst. Des. Appl. 2017, 557, 974-983.

21. Lam, H.W.; Wu, C. Finding Influential Ebay Buyers for Viral Marketing a Conceptual Model of Buyerrank. In Proceedings of the 2009 International Conference on Advanced Information Networking and Applications, Bradford, UK, 26-29 May 2009.

22. Kim, J.; Lee, W.; Yu, H. Ct-Ic: Continuously Activated and Time-Restricted Independent Cascade Model for Viral Marketing. Knowl. Based Syst. 2014, 62, 57-68. [CrossRef]

23. Shuai, H.H.; Shen, C.Y.; Hsu, H.C.; Yang, D.N.; Chou, C.K.; Lin, J.H.; Chen, M.S. Revenue Maximization for Telecommunications Company with Social Viral Marketing. In Proceedings of the 2015 IEEE International Conference on Big Data (Big Data), Santa Clara, CA, USA, 29 October-1 November 2015.

24. Zhou, L. Research on Ca Model of Viral Marketing Diffusion Simulation. In Proceedings of the 2015 International Conference on Economics, Social Science, Arts, Education and Management Engineering, Xi'an, China, 12-13 December 2015.

25. Ding, H. Study on Diffusion Mechanism of Viral Marketing Based on Social Networking Web Sites. In Proceedings of the WHICEB, Wuhan, China, 31 May-1 June 2014.

26. Alsuwaidan, L.; Ykhlef, M. Toward Information Diffusion Model for Viral Marketing in Business. Int. J. Adv. Comput. Sci. Appl. 2016, 7, 637-646. [CrossRef]

27. Li, X.; Cheng, S.; Chen, W.; Jiang, F. Effective Method for Promoting Viral Marketing in Microblog. In Proceedings of the 2013 International Conference on Social Computing, Alexandria, VA, USA, 8-14 September 2013.

28. Serrano, E.; Iglesias, C.A. Validating Viral Marketing Strategies in Twitter Via Agent-Based Social Simulation. Expert Syst. Appl. 2016, 50, 140-150. [CrossRef]

29. Wu, H.; Liu, W.; Yue, K.; Huang, W.; Yang, K. Maximizing the Spread of Competitive Influence in a Social Network Oriented to Viral Marketing. In Web-Age Information Management; Springer International Publishing: Cham, Switzerland, 2015.

30. Yang, J.; Yao, C.; Ma, W.; Chen, G. A Study of the Spreading Scheme for Viral Marketing Based on a Complex Network Model. Phys. A Stat. Mech. Its Appl. 2010, 389, 859-870.

31. Rodrigues, H.S.; Fonseca, M. Can Information Be Spread as a Virus? Viral Marketing as Epidemiological Model. Math. Methods Appl. Sci. 2016, 39, 4780-4786. [CrossRef]

32. Shakarian, P.; Paulo, D. Large Social Networks Can Be Targeted for Viral Marketing with Small Seed Sets. In Proceedings of the 2012 IEEE/ACM International Conference on Advances in Social Networks Analysis and Mining, Istanbul, Turkey, 26-29 August 2012.

33. Yeoh, E.; Othman, K.; Ahmad, H. Understanding Medical Tourists: Word-of-Mouth and Viral Marketing as Potent Marketing Tools. Tour. Manag. 2013, 34, 196-201. [CrossRef]

34. Bublitz, M.G.; Peracchio, L.A. Applying Industry Practices to Promote Healthy Foods: An Exploration of Positive Marketing Outcomes. J. Bus. Res. 2015, 68, 2484-2493. [CrossRef]

35. Falát, L.; Martin, H. The Influence of Marketing Communication on Financial Situation of the Company-A Case from Automobile Industry. Procedia Eng. 2017, 192, 148-153. [CrossRef]

36. Alsuwaidan, L.; Ykhlef, M.; Alnuem, M.A. A Novel Spreading Framework Using Incremental Clustering for Viral Marketing. In Proceedings of the 2014 IEEE/ACS 11th International Conference on Computer Systems and Applications (AICCSA), Doha, Qatar, 10-13 November 2014.

37. Meyliana, M.A.; Henry, E.W.; Stephen, W.S. The Influence of Customers Communication Behaviour in the Implementation of 21cineplex Viral Marketing Using the Social Networking Site Facebook. Commit J. 2015, 9, 11.

38. Bitner, M.J. The Impact of Physical Surroundings on Customers and Employees. J. Mark. 1992, 56, 57-71. [CrossRef]

39. Mehrabian, A.; James, A.R. A Verbal Measure of Information Rate for Studies in Environmental Psychology. Environ. Behav. 1974, 6, 233-252.

40. Mazaheri, E.; Richard, M.-O.; Laroche, M. Online Consumer Behavior: Comparing Canadian and Chinese Website Visitors. J. Bus. Res. 2011, 64, 958-965. [CrossRef] 
41. Chen, H.; Duan, W.; Zhou, W. The Interplay between Free Sampling and Word of Mouth in the Online Software Market. Decis. Support Syst. 2017, 95, 82-90. [CrossRef]

42. De Keyzer, F.; Dens, N.; De Pelsmacker, P. The Impact of Relational Characteristics on Consumer Responses to Word of Mouth on Social Networking Sites. Int. J. Electron. Commer. 2019, 23, 212-243. [CrossRef]

43. Beretta, E.; Yasuhiro, T. Global Stability of an Sir Epidemic Model with Time Delays. J. Math. Biol. 1995, 33, $250-260$. [CrossRef]

44. Liu, X.; Weijun, W.; Jinke, W.U. Celebrity and Ordinary Users: A Comparative Study of Microblog User Behaviors on Sina Weibo. Chin. J. Libr. Inf. Sci. 2015, 8, 83-95.

(C) 2020 by the authors. Licensee MDPI, Basel, Switzerland. This article is an open access article distributed under the terms and conditions of the Creative Commons Attribution (CC BY) license (http://creativecommons.org/licenses/by/4.0/). 